Relación entre los actores y niveles de confianza en centros de educación secundaria del cantón Guayaquil (Ecuador)

\title{
Relationship among the Actors and Levels of Trust in Secondary Education Centers of the Guayaquil Canton (Ecuador)
}

Mónica Rebeca Franco Pombo. Universidad Católica Santiago de Guayaquil (Ecuador).

franco.monica@gmail.com

Antonio Luque de la Rosa. Universidad de Almería. aluque@ual.es

María del Mar Fernández Martínez. Universidad de Almería. mfm386@ual.es

Rafaela Gutiérrez Cáceres. Universidad de Almería rcaceres@ual.es

\section{RESUMEN.}

La política pública del Ecuador ha ubicado a la mejora de la calidad educativa como uno de los principales objetivos de la gestión gubernamental. Los constructos clima-escolar, clima organizacional, clima de trabajo y clima institucional son utilizados en diferentes entornos para acentuar la importancia de la relación que se establece entre un ambiente de gestión satisfactorio y la calidad de resultados en las organizaciones.

A través del presente estudio se planteó como objetivo el análisis de las variaciones de la relación entre los actores y los niveles de confianza entre los actores del clima organizacional escolar de acuerdo con el nivel socioeconómico, el rol desempeñado en la comunidad educativa o el tipo de centros escolares.

El estudio corresponde a una investigación de tipo no experimental, descriptivacomparativa, mediante técnicas como la encuesta, la entrevista y el grupo de discusión, ajustándose a la metodología mixta de acuerdo a los objetivos y sentido de la investigación planteada.

Como resultados apreciaremos que las relaciones entre los actores y los niveles de confianza de los actores muestran indicadores mayoritariamente positivos en función de las respuestas de los participantes en el estudio. Sin embargo, el porcentaje de percepciones negativas $(24,34 \%)$ es un dato a tener en cuenta, puesto que podría sugerir que subyacen en esas percepciones indicadores de desconfianza que habría que tomar en cuenta para posibles intervenciones posteriores.

En conclusión, los centros escolares participantes de este estudio han construido un clima organizacional escolar mayoritariamente positivo, lo cual genera espacios favorables a procesos de innovación y cambio. 


\section{PALABRAS CLAVE.}

Clima escolar, percepción, innovación, reforma.

\section{ABSTRACT.}

The public policy of Ecuador has placed the improvement of educational quality as one of the main objectives of government management. The climate-school constructs, organizational climate, work climate, and institutional climate, are used in different environments to accentuate the importance of the relationship established between a management environment factor and the quality of results in organizations.

Throughout this study, the objective has been to analyze the variations in the relationship among the actors, and the levels of trust between the actors of the school organizational climate, according to the socioeconomic level, the role played in the educational community, or the type of socio-educational center.

The study follows a new approach of an experimental, descriptive-comparative investigation, using techniques such as the survey, the interview, and the discussion group, adjusting to the mixed methodology according to the objectives and sense of the research proposed.

In consideration of the results, we will appreciate that the relationships between the actors and the confidence levels of the actors show mostly positive indicators based on the responses of the participants in the study. However, the percentage of negative perceptions $(24.34 \%)$ is a factor to consider, since it might suggest that these perceptions underlie indicators of distrust that should be taken into account for any future interventions.

In conclusion, the schools participating in this study have built a mostly positive school organizational climate, which generates favorable spaces for innovation and change processes.

\section{KEY WORDS.}

School climate, perception, innovation, reform.

\section{Introduction.}

Ecuador has stated that NDO, in recent years, has been one of the main goals of its administration, improving education in their territory. Thus, with the National Plan for Good Living 2009-2013 and 2014-2017, it is postulated that "education is the fundamental basis of social justice" (Senplades, 2013, p.24).

A key aspect of the reform is, undoubtedly, the legislative action that resulted in the promulgation of the Organic Law of Intercultural Education (2011) and the Regulation to that law (2012). From the effective date of these legal bodies momentous changes were implemented in the educational system of Ecuador, which were called by the Ministry of Education as"twenty breaks in the status quo".

These ruptures have been classified into four major groups: (a) those that reconceptualize education as a right of individuals and communities, (b) those that point to a profound change in the structure of the national education system, (c) those that seek to overcome 
the old paradigms of quality and educational equity to ensure better student learning, and (d) those that contribute to evaluating the teaching profession (Mineduc, 2012, p.11).

The period 2007-2014 has been substantially different for the education sector in Ecuador. The decision to place education as a strategic line of action of public policy has allowed the administrators of the educational system to move from a structure totally devoid of resources and lacking strategic direction, to a much more coherent reality in which it has prevailed a sustained investment. Likewise, the design and implementation of technical actions that underpin the quality, issuance and implementation of educational policies aimed at overcoming the serious difficulties that, in all orders, convulsed the sector and violated the right of citizens to access a quality education.

Once the implementation of these changes has been carried out, it is necessary to study the articulation of a new legal framework, as well as the issuance of a network of educational policies and administrative regulations -which led to changes of all kinds (curricular, organizational, and administrative) -, have influenced the school climate of the educational communities of Guayaquil cantón, being these key facts in the role that teachers develop ( Retana Alvarado and others, 2018 ; Weinstein and Raczynski , 2018 ).

The climate-school constructs, organizational climate, work climate, and institutional climate, are generic ideas diffused in different environments to accentuate the importance of the relationship that is established between a management environment factor and the quality of results obtained in organizations (Asensio Muñoz and Fernández Díaz, 1991 ; Escarbajal Fruits , Caballero García and Roda Páez , 2019) , stimulating the capacity for school innovation ( Gil López, Antelm Lanzat and Cacheiro González, 2018) and coexistence in educational centers ( Huber , MontpointGaillard Y Weisheimer , 2018).

Thus, we will conceive the organizational climate in schools as a "multidimensional construct" (Toro Álvarez and Cabrera Gómez, 1998), which results from amalgamating the set of perceptions of the participating actors themselves. (Leiva Olivencia , 2015 , Mendoza González and Barrera Baca , 2018), because of how they feel and live interpersonal relationships ( Fernández Batanero, 2015 ; Pacheco Salazar , 2018), the degrees of satisfaction, the fulfillment of expectations, the course of the dialogic informationcommunication, the actions of leadership, and addressing within a structure committed to educational purposes ( Delgado Algarra, 2015).

\section{Method.}

\subsection{Objectives.}

1. Analyze the variations of the perception of the relationship between the actors and the levels of confidence, and their incidence in the school organizational climate, according to the socioeconomic level or the type of centers and/or schools to which the actors of the educational communities participating in this study belong.

2. Recognize if the perceptions of climate organizations in schools, positioned as representations in the perceptual world of the actors of the educational community, are similar or different according to their roles as providers and beneficiaries of the educational service, respectively.

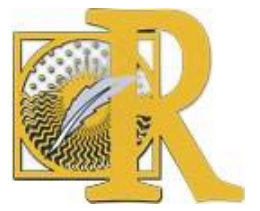


3. Analyze how the organizational climate, product of the perceptions of the members of the educational community about the relationship between the actors and the levels of trust, favors or not the implementation of educational change proposals.

In this sense, we intend to deepen the dimension of the dynamics of coexistence, specifically in the perception of the relationship between the actors and the levels of trust between the participating subjects.

\subsection{PARTICIPANTS depending on variables analyzed}

Intervening or socio-demographic variables that have been identified as such, are those features of the structure, type of actors / stakeholders in the education community, such centers or socioeconomic status, which are considered in the school system, may have some connection with the object of study .

Thus, the composition of these variables included: four types of actors, four socioeconomic levels, and three types of schools.

Table 1.Composition of the intervening variable.

\begin{tabular}{lcl}
\hline \multicolumn{1}{c}{ Type of actors } & Socioeconomic level (NSE) & \multicolumn{1}{c}{ Types of schools } \\
\hline Managers (R) & NSE Low-low & Traditional public \\
Teachers (D) & NSE Medium-low & Public Replicas \\
Students (E) & NSE Medium-high & Individuals \\
Parents (PPFF) & NSE High & \\
\hline
\end{tabular}

The actors correspond to the members of the educational communities: managers $(R)$, which include the rectors and vice-rectors (7) of the school, also recognized in the Ecuadorian context as the authorities of the educational institutions, each of them with specific functions provided in the General Regulation of the Organic Law of Intercultural Education (LOEI) ; I I teachers (7), who, in an Ecuadorian context, make mention rector and rector of a center, secondary or primary school, and Spanish terminology, corresponds to the Director and Assistant Director of the teachers responsible for managing climate classroom learning (D), who were selected in each of the centers participating in the study; students $(E)$, who belonged to the registration of the school enrollment studied, being young people enrolled in the second and third year of the general baccalaureate unified; the parents (FAQ), who were chosen on the basis of the same record, and defined themselves as representatives of the students in the sample.

The socioeconomic level, on the other hand, was defined based on data and indicators offered by the National Institute of Census and Statistics (INEC), based on the social stratification survey INEC (2012), whose data are public knowledge. Each level has been considered in terms of consistent variables such as: a) Type of housing; b) Economy; c) Assets and d) Level of education.

On the other hand, the selection of schools responded to two clearly defined factors: a) sustainability level, this is the origin of the resources that financed them (public and private) and b) the denomination of the center (traditional and replicas). 


\subsection{Overview of the research (approach and methodology)}

Once we have clarified the subject of this investigation and defined its objectives, we proceed to discuss the study design made, specifying aspects such as the type of research to which it was attached, methodological approach used, features, and components and techniques employed in this process.

The study presented corresponds to a non-experimental, descriptive type of research, which was adjusted to a type of mixed methodology.

Confirming that it was a descriptive-comparative study, it is now appropriate to specify the reasons for such attributes for this approach. It was descriptive because it was concerned with obtaining objective, accurate, and systematic data on the school organizational climate in the specific case of eight schools in the Guayaquil canton; and comparative, because they were determined and analyzed perceptions of perceptions in different groups.

In this sense, it was intended, not only, to describe the relational phenomena that were manifested in the selected schools, but to establish comparisons according to type of actors, type of centers, and socioeconomic level, in order to identify and understand the properties of the school organizational climate construct. It was, in short, an approximation to the reality of schools from the perspective of the perceptions of its members.

\subsection{Applied materials (techniques, instruments) and population samples.}

\section{$>\quad$ Quantitative phase (questionnaire):}

In accordance with the aforementioned, the sample was constituted from a population composed of all the high school students registered in the statistics of the Ministry of Education (2013), as enrolled in the second and third year of high school during the 2013 academic period. -2014, their parents or representatives, the baccalaureate teachers and the directors of the public and private schools that participate in the study.

Table 2. Characteristics of informants sex and average age.

\begin{tabular}{cccccc}
\hline Features & Students & Teachers & PPFF & Managers & Total percentage \\
\hline Mens & $60 \%$ & $53.30 \%$ & $19 \%$ & $37.50 \%$ & $43.9 \%$ \\
\hline Women & $39.80 \%$ & $46.70 \%$ & $81 \%$ & $62.50 \%$ & $56.04 \%$ \\
\hline Average age & 18.2 & \multicolumn{2}{c}{48.5} & 52.5 & 50.6 \\
\hline
\end{tabular}

In the context of estimating a population sample, the variant of the proportions sampling formula with two definitional characteristics was selected, which offered a confidence level of $95.5 \%$. The sample size was calculated based on data from educational statistics, whose source is, "Institute Master File Educational Framework", describing the student population and environment in public and private teaching (Ministry of Education, 2013). 
Table 3. Composition of the sample.

\begin{tabular}{|c|c|c|c|c|c|}
\hline \multirow[b]{2}{*}{ Schools } & \multicolumn{5}{|c|}{ FEES ASSIGNED BY ACTORS } \\
\hline & Students & Teachers & Parents & Managers & Total \\
\hline Replica College Aguirre Abad (CRAA) & 40 & 60 & 40 & two & 142 \\
\hline Simón Bolívar Replica School (CRSB) & 70 & 80 & 70 & two & 222 \\
\hline $\begin{array}{l}\text { Ana Paredes Traditional School } \\
\text { (CTAP) }\end{array}$ & 65 & fifty & 75 & two & 193 \\
\hline $\begin{array}{l}\text { Traditional School Joaquín Gallegos } \\
\text { (CTJGL) }\end{array}$ & 135 & 80 & 150 & two & 367 \\
\hline $\begin{array}{l}\text { Vicente Rocafuerte Traditional School } \\
\text { (CTVR) }\end{array}$ & 200 & 155 & 200 & two & 557 \\
\hline $\begin{array}{l}\text { Jefferson Bilingual Private School } \\
\text { (CPBJ) }\end{array}$ & 40 & 19 & 7 & two & 68 \\
\hline $\begin{array}{l}\text { Private School Liceo Los Andes } \\
\text { (CPLA) }\end{array}$ & 63 & 16 & 22 & two & 54 \\
\hline $\begin{array}{l}\text { Santiago Mayor Private School } \\
\text { (CPSM) }\end{array}$ & 40 & 28 & 40 & two & 110 \\
\hline TOTAL & 653 & 488 & 604 & 16 & 1761 \\
\hline
\end{tabular}

Once the sample size was defined, an intentional non-probabilistic sampling was chosen, which provided quotas for informants, based on the knowledge of the researchers about the population under study. Thus, for example, the quotas allocated, that is, the number of informants in each school, were determined according to the enrollment rate of the baccalaureate in each of them. Then, the informants were selected on the basis of the characteristics and attributes of the population, so that their representativeness was obtained in two ways: a) the allocation of representative quotas of the population selected and b) the study of the profiles of the groups that made up the population.

In view of the above, the selection of the type of sampling responded to the need to achieve greater utility of the information that would be obtained from a model that considered: groups selected as key informants, (teachers, managers, students, and parents of families; and scenarios (eight schools in the Guayaquil canton).

Table 4. Population and character of the sample.

\begin{tabular}{cccc}
\hline INFORMANTS & POPULATION & SAMPLE & $\begin{array}{c}\text { CONFIDENCE } \\
\text { INTERVAL }\end{array}$ \\
\hline High school students & 14,457 & 653 & 3.75 \\
\hline Teachers of baccalaureate & 767 & 488 & 2.68 \\
\hline Parents & 14,457 & 604 & 3.9 \\
\hline Managers & 16 & 16 & 0 \\
\hline
\end{tabular}

The structure of the survey was constituted with affirmative propositional reagents, to be measured through a Likert scale that sought a response in a range of strongly disagree to very scarcely agree, and considered in 0-1 the neutral top (without elements for answer and undecided). The informants were urged to respond to each of the statements by selecting a

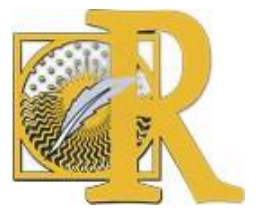
entre los actores y niveles de confianza en centros de educación secundaria del cantón Guayaquil (Ecuador) International Journal of Educational Research and Innovation (IJERI), 12, 184-202 
point in a continuous gradation of approval-disapproval (5, strongly agree, 4 agree, 3 disagree, 2 strongly disagree, 1 no elements to answer and 0 , indecisive).

For the validation of the contents, the convocation of experts was resorted to For this, three university professors with experience in education and in research processes received, together with detailed instructions, the instruments accompanied by an evaluation form. They were asked to judge individually, separately, the congruence of the items and the theoretical content of the object of study, the clarity in the formula of each item, and the contingency of bias to be able to induce the answer or not.

Although, it was important to have this report on the validity of the contents subscribed by experts in the subject, we also sought to appreciate the reliability of the instrument, that is, it was intended to evaluate the homogeneity of the items. Therefore it was decided to use the Cronbach's alpha, referred to as particularly useful for this case, because the instrument analyzed included a scheme of polytomous responses.

The Cronbach alpha coefficient is identified as a powerful resource for measuring the reliability of a measurement scale that, according to McMillan and Shumacher (2012), shows the internal consistency of the questions or item of a measuring instrument, ie. , indicates the correlation between each of the questions, in which a value greater than 0.7 reveals a strong relationship between them. Thus, the closer to 1 the value of alpha, the higher the internal consistency of the items you are analyzing, with alpha> 0.9 an excellent coefficient.

\section{$>$ Qualitative phase.}

In this project, the purpose of reconstructing the perception of the reality studied was based on the opinions, evaluations, beliefs and feelings of the students informants. In this sense, a direct and systematic exploration of the mental representations (perceptions) was achieved, which, on the phenomenon relationship between the actors and levels of trust between the actors, had been positioned in the collective belief of the actors. participating educational munities; constituting these, possibly, in factors that drive or delay educational reform.

Among the different techniques that are applied in qualitative research, it was decided to use: interviews and discussion groups.

The subjects participating in this phase were randomly selected from the same base or register with which they were counted for the quantitative phase, therefore the informants were chosen according to the following characteristics: a) Executives, all the authorities (rector and vice-rector) of the school center; b) Teachers, holders in $70 \%$ and $30 \%$ of their contract; c) Students , $50 \%$ of the 2nd year of the baccalaureate, and $50 \%$ of the 3rd year of the baccalaureate and d) the parents of the families, selected in each establishment. 


\subsection{Data analysis procedure.}

In the case of quantitative, one-comparative descriptive analysis for which descriptive statistical methods are employed as mean, standard deviation, frequency, percentages and nonparametric test Chi Square in calculating the goodness of fit was applied in the making.. With respect to the latter, goodness of fit, is a statistical model used to describe the degree of adjustment of a set of real observations to a theoretical distribution model, revealing the possible discrepancies between the observed values and the expected values in the frequencies that are analyzed in a study (McMi Llan and Schumacher, 2012). This analysis was carried out using statistical software IBM SPSS version 19.

In the case of qualitative data, the first thing that was done was to transcribe the data for analysis, and then one proceeded to sort and classify the information, so that we had an easily accessible product. Once reported, it was codified, and the informant subjects and their verbalizations were related to the study categories, the specialized ATLAS software was used for it (version 10.36).

\section{Results.}

\subsection{Analysis of results: perception of the relationship between the actors and levels of trust between the actors.}

As already mentioned, two categories were analyzed around which the perceptions of the subjects occur, registering as positive, negative, or neutral.

In the following section we present a synthesis of some more relevant results:

How are the relationships between the actors of the educational communities participating in the study perceived, and in what way do these perceptions configure an organizational climate that favors or jeopardizes the educational change that is to be achieved?

At a global level, the relationships between the actors of the educational communities appreciated in the sample results indicate, in general, positive responses from the actors with a weighted average of $68.71 \%$, while negative responses only reached $22.52 \%$.

The descriptive analysis shows a significantly higher percentage of positive responses than negative responses, a difference that is accentuated in the category "Relation between the actors ", with a weighted average of $79.28 \%$, which means that approximately 4 out of 5 actors from the educational communities studied considered this relationship as positive. 
Table 5. General results of the perceptions of the categories

\begin{tabular}{cccc}
\hline CATEGORIES & Positives & Negatives & Neutral \\
\hline $\begin{array}{c}\text { Relation between the } \\
\text { actors (REA) }\end{array}$ & 79.28 & 14.68 & 6.04 \\
\hline $\begin{array}{c}\text { Levels of trust } \\
\text { between the actors } \\
\text { (NCA) }\end{array}$ & 64.42 & 24.34 & 11.24 \\
\hline
\end{tabular}

\subsubsection{REA Category.}

In this category, the information is structured from a set of 37 items, distributed in the four survey forms. These items, formulated in propositions, inquire about how the relationships between authorities-teachers-students-parents are established. The relationship between the actors is reflected in the following table, situating in mostly positive perceptions because the average $\geq 4$ reached a general average of $(81.14 \%)$.

It could be interpreted as a favorable assessment of the framework of relationships that are established within the schools that participate in the study.

Table 6. Overall results of the perceptions of the REA categories.

\begin{tabular}{cccc}
\hline CATEGORY & Positives & Negatives & Neutral \\
\hline REA & 81,14 & 12.9 & 5.96 \\
\hline
\end{tabular}

\section{a) Influence of the type of actors in the REA Category.}

The relationship between the actors appears fairly well evaluated (Figure 1), with the highest perceptive point in the managers $(94.5 \%)$, followed by teachers $(89.47 \%)$. However, parents (77.64\%) and students, with (72.99\%), mark a downward trend in their perceptions.

Within the framework of relations between the actors of the educational communities, the LOEI in its Art. 6 provides as an obligation of the State: "Guarantee that educational institutions are democratic spaces for the exercise of rights and peaceful coexistence" (LOEI, 2011), and as a result of this, work has been carried out in recent years on the participatory construction of the code of coexistence in each of the schools. It is a management that must be strengthened.

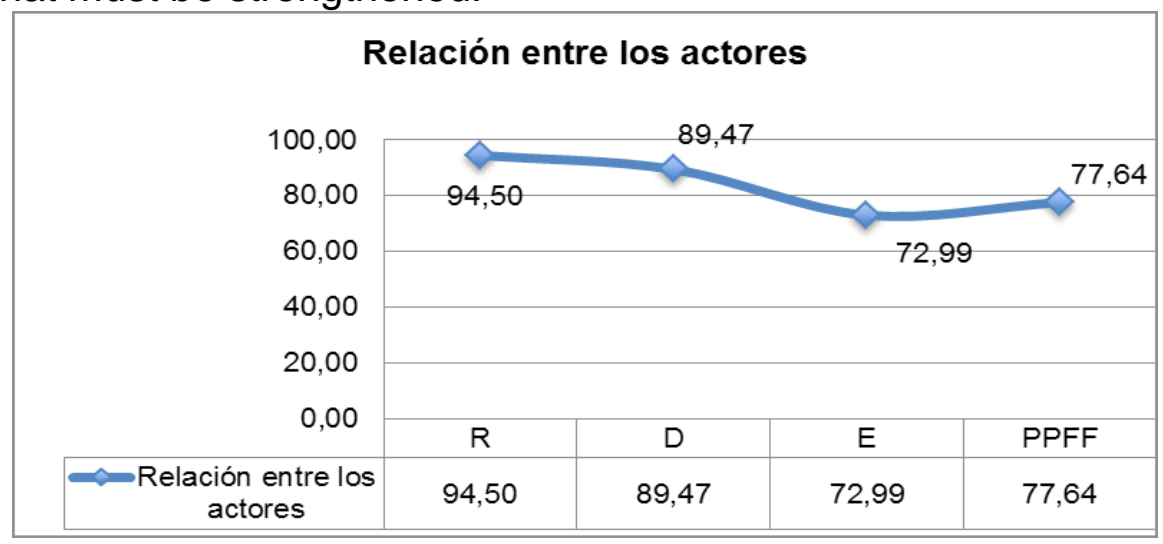

Figure 1. Comparison of the REA by type of actors. 
b) Influence of the type of center in the REA Category.

Once analyzed the data by level of support, we see the perception of managers clearly favored in the private sector $(89.60 \%)$, compared to a fiscal sector whose positive perceptions reach $84.35 \%$. The fiscal professors with $88.91 \%$ and the private teachers with a $93.25 \%$ form a mostly positive perception in the whole of teaching or service providers. In the private establishments, the actors perceive a better level of interactions in the social body that make them up. Even so the perception of the students is located as favorable, but at a lower level: particular, $73.34 \%$; fiscal, $72.89 \%$.

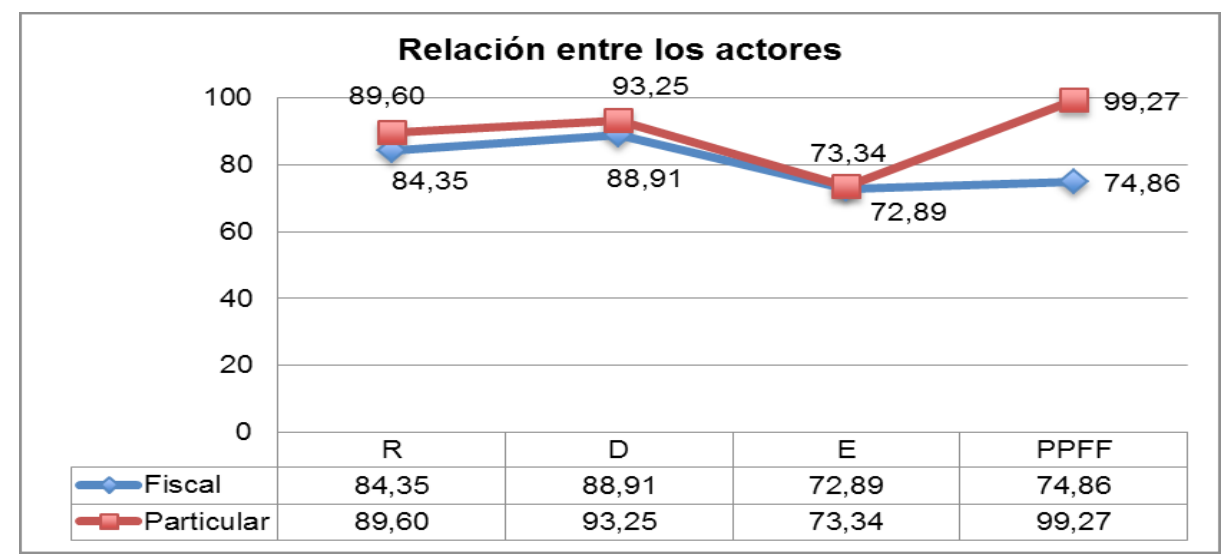

Figure 2. Comparative by type of REA centers.

Phrases like those that emerged in the interviews and discussion groups are enlightening to interpret the perceptions that students have regarding relationships in the school world:

Okay, yes; when you try to talk to them, they say "shut up, and do not talk to me"; and you want to talk, and defend yourself, but they do not listen. Since they are teachers, and we are students, they supposedly have the right to prevail (EECFTJG).

They give us many opportunities, that's where I do not agree, because there are people who present their work the day that is here, and others later; and this does not seem quite right, as all of us strive to improve, and all of us are equal (EECRSB).

The spectacle of the relationships (Table 7 ), which are marked in the interactions of the members of the educational communities under study, showed a quite positive outlook, with the perceptions of the particular sector being higher than those found in the fiscal schools (public support). Executives, teachers, and parents, scored an average $\geq 4$, which denotes a broad sense of satisfaction with relationships. With respect to the criterion of directors, teachers, and parents of the particular sector, found lower scores, but some equally positive as the same actors in the fiscal sector. However, students scored lower on a Mean $\geq 4$. 
Table 7. Comparison of perceptions of actors by type of school REA.

\begin{tabular}{ccccccccc}
\hline \multicolumn{2}{c}{ ACTORS } & \multicolumn{2}{c}{ R } & \multicolumn{2}{c}{ D } & \multicolumn{2}{c}{ AND } & \multicolumn{2}{c}{ PP FF } \\
\hline Perceptions & FISCAL & PART. & FISCAL & PART. & FISCAL & PART. & FISCAL & PART. \\
\hline POSITIVE & $84.35 \%$ & $89.60 \%$ & $88.91 \%$ & $93.25 \%$ & $72.89 \%$ & $73.34 \%$ & $74.86 \%$ & $99.27 \%$ \\
\hline NEGATIVES & $15.65 \%$ & $10.40 \%$ & $10.32 \%$ & $5.55 \%$ & $19.56 \%$ & $19.67 \%$ & $15.33 \%$ & $0.12 \%$ \\
\hline NEUTRAS & 0 & 0 & $0.77 \%$ & $1.19 \%$ & $7.55 \%$ & $6.99 \%$ & $9.81 \%$ & $0.61 \%$ \\
\hline
\end{tabular}

When the perception is analyzed by school centers (Table 8 ), it is found that the most positive view is found in private schools. Under the D1C3, stands among them the CPBJ, with higher positive perceptions highlighted in green. The lowest scores (marked in red) are obtained by the CFTVR. It is relevant to point out the unflattering perception of the students of the CFRAA (60\%). The importance of building a framework of favorable relationships becomes a basic requirement for educational communities that undergo processes of change, above all because of the strength on which motivation and commitment must be based.

Table 8. Comparative of positive perceptions of educational centers.

\begin{tabular}{ccccc}
\hline D1C3 & RECTORS & TEACHERS & STUDENTS & PP FF \\
\hline CFRAA & $84.4 \%$ & $90.0 \%$ & $60.0 \%$ & $85.6 \%$ \\
\hline CFRSB & $84.0 \%$ & $91.5 \%$ & $80.0 \%$ & $78.9 \%$ \\
\hline CFTAP & $80.0 \%$ & $93.3 \%$ & $86.5 \%$ & $90.8 \%$ \\
\hline CFTJGL & $93.3 \%$ & $90.0 \%$ & $75.0 \%$ & $72.7 \%$ \\
\hline CFTVR & $80.0 \%$ & $82.9 \%$ & $67.1 \%$ & $66.9 \%$ \\
\hline CPBJ & $95.6 \%$ & $92.1 \%$ & $74.1 \%$ & $98.8 \%$ \\
\hline CPLA & $84.4 \%$ & $96.1 \%$ & $77.4 \%$ & $98.5 \%$ \\
\hline CPSM & $88.9 \%$ & $92.4 \%$ & $66.3 \%$ & $99.8 \%$ \\
\hline
\end{tabular}

c) Influence of the NSE in the REA Category.

In this case, the analysis by socioeconomic strata shows that the framework of the relationships is favored and perceived as mostly positive by the reporting subjects of each level. The highest perceptual point $(85.2 \%)$, is located in the medium-high layer, and the lowest $(75.5 \%)$ in the low-low NSE.

Table 9. General results of the REA by NSE.

\begin{tabular}{ccccc}
\hline D1C3 & NSE Low-Low & NSE Medium Low & $\begin{array}{c}\text { NSE Medium- } \\
\text { High }\end{array}$ & NSE High \\
\hline Positives & $75.5 \%$ & $83.4 \%$ & $85.2 \%$ & $82.9 \%$ \\
\hline Negatives & $14.7 \%$ & $12.4 \%$ & $12.2 \%$ & $9.4 \%$ \\
\hline Neutral & $9.8 \%$ & $4.1 \%$ & $2.5 \%$ & $7.6 \%$ \\
\hline
\end{tabular}




\subsubsection{NCA category.}

In this category, the search was guided through 15 items, which inquired about the level of trust existing in each of the actors about those with whom it relates. It was intended to explore, then, the perceptions of the students regarding the trust they placed in their parents, teachers, and school directors; in the same way, how the level of teacher confidence in their managers was valued, and the trust of the managers in the teachers of the center's payroll.

This content made sense in the study because trust as a value, which is built inside schools, is the foundation of the work and collaboration relationships of school organizations that are experiencing accelerated change processes. Confidentiality, a sense of community and solidarity are strengthened in the trust placed among members of a community around their capabilities and their motivations.

Table 9. General results of the perceptions of the NCA category.

\begin{tabular}{cccc}
\hline Category & Positives & Negatives & Neutral \\
\hline NCA & 64.42 & 24.34 & 11.24 \\
\hline
\end{tabular}

The results obtained by exploring the perceptions of the subjects participating in the study, show perceptions may be hesitant $(64.42 \%)$, though basically positive. However, the percentage of negative perceptions (24.34\%) is a factor to consider, since it might suggest that underlie these perceptions indicators of distrust that should be taken into account for any future interventions.

\section{a) Influence of the actors in the NCA Category}

In the study analyzed, the level of confidence on average appears less favored in the perception of parents and students, while teachers and principals appreciate this construct as something achieved at a good level in their educational institutions. Once again, a trend of lower perceptions is expressed in the segment of users of the educational service. This data can be interpreted as a symptom of dissatisfaction that needs to be addressed since the levels of trust between the actors of the schools pay positively to the construction of school environments that promote an integral formation of the students.

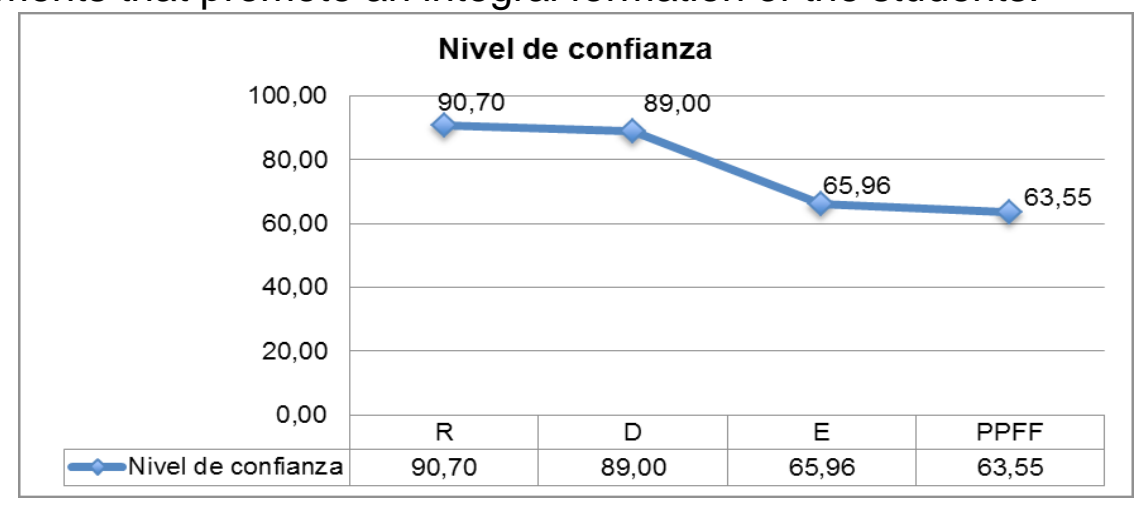

Figure 3. Comparative NCA by type of actors. 
The actors of the educational communities of the case under study, express a level of confidence that is mostly positive, between authorities $(90.70 \%)$ and teachers (89.00\%). However, they charge a decreasing course when it comes to students $(65.96 \%)$ and parents $(63.55 \%)$; At the teaching level, there is favorable confidence in the role that each of the actors plays. However, users of the service again express a perception with a downward trend, which is in line with the general results that have been shown up to now. If you collect the verbalizations produced by discussion groups and interviews, you can find statements that could explain the data:

We trust teachers and managers because the relationship between them and our children is quite good, although sometimes they can evince tensions, because perhaps there may be a lack of clarified tasks, or a lack of communication with respect to a student's work. Almost always that leads to a particular difficulty with the student, who is mistakenly unilaterally caught at fault (E.PF.CPBJ).

Trust, at $100 \%$, I do not think so. Teachers and authorities do not always have the school or the classroom as their first work effort. It is as if it were not important for them what they have to do every day at school (E.PF.CTJG).

\section{b) Influence of the tip or center in the NCA Category}

The actors of the particular educational and fiscal communities that participated in this study, expressed at the level of teaching (managers and teachers), a perception that is mostly positive with respect to the levels of trust, which have been built in their respective centers. On the other hand, students re-express a less favorable positive perception $(67.92 \%)$, in the fiscal sector and $(58.94 \%)$ in the private sector. The parents of the fiscal sector register the lowest positive perception of the category (34.78\%).

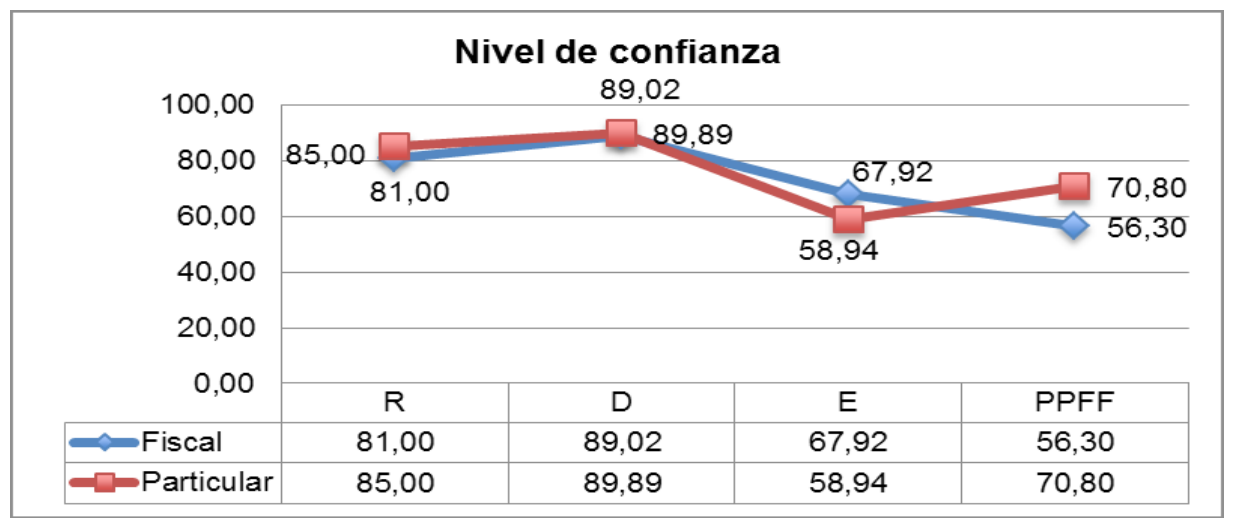

Figure 4.. Comparison of NCA by type of actors.

These data may reflect the positioning of an impoverished view in the so-called beneficiaries of the service. This fact can mark warning indicators for the educational system, in general, which, as is known, is advocating abundant and complex change strategies. The confidence in the decision making on the part of the directors, making a vote in favor of the performances within the school, becomes an element of openness to change.

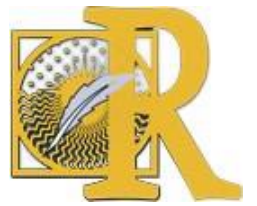


In the comparison of the perceptions of the actors by type of school, a different level of trust was found. Positive perceptions appear more or less even in the case of fiscal (89.02\%) and particular $(89.89 \%)$, students perceive confidence levels also positive, but in smaller proportions, fiscal (67.92\%) and individuals, significantly lower (58.94\%).

In the case of parents, perceptions fluctuate, also in positive ranges, fiscal (56.30\%) and private $(70.80 \%)$. These data show agreement with the general perceptions described in previous sections and allow Prospect the need to work on concrete actions to improve relations with students and parents in both sectors.

Table 10. Comparison of perceptions of actors by type of school NCA.

\begin{tabular}{ccccccccc}
\hline ACTORS & \multicolumn{2}{c}{ R } & \multicolumn{2}{c}{ D } & \multicolumn{2}{c}{ AND } & \multicolumn{2}{c}{ PP FF } \\
\hline Perceptions & FISCAL & PART. & FISCAL & PART. & FISCAL & PART. & FISCAL & PART. \\
\hline POSITIVE & $81.00 \%$ & $85.00 \%$ & $89.02 \%$ & $89.89 \%$ & $67.92 \%$ & $58.94 \%$ & $56.30 \%$ & $70.80 \%$ \\
\hline NEGATIVES & $19.00 \%$ & $15.00 \%$ & $9.88 \%$ & $10.58 \%$ & $22.58 \%$ & $29.27 \%$ & $26.64 \%$ & $25.42 \%$ \\
\hline NEUTRAS & & & $1.10 \%$ & $0.53 \%$ & $9.50 \%$ & $11.79 \%$ & $17.06 \%$ & $3.78 \%$ \\
\hline
\end{tabular}

The level of confidence translates into positive perceptions of the set of actors in each of the school centers participating in this study; in this case, the perceptions appear differentiated. The highest line is found in the CFTAP, from the traditional fiscal centers; whereas, the lowest perceptual line is given in the case of a replica center (CFRAA). Another relevant and coherent fact with other dimensions is the existence of a generalized downward trend in the students' mood, with the exception of the CFTAP. These data suggest that within educational establishments it is necessary to consolidate leadership and establish much more proactive relationships with students.

Table 11. Comparative of positive perceptions of educational centers.

\begin{tabular}{ccccc}
\hline NCA & RECTORS & TEACHERS & STUDENTS & PP FF \\
\hline CFRAA & $80.0 \%$ & $88.3 \%$ & $51.8 \%$ & $50.0 \%$ \\
\hline CFRSB & $85.0 \%$ & $97.5 \%$ & $71.6 \%$ & $51.4 \%$ \\
\hline CFTAP & $80.0 \%$ & $96.0 \%$ & $84.0 \%$ & $72.0 \%$ \\
\hline CFTJGL & $85.0 \%$ & $88.8 \%$ & $71.3 \%$ & $56.0 \%$ \\
\hline CFTVR & $75.0 \%$ & $82.8 \%$ & $62.4 \%$ & $55.0 \%$ \\
\hline CPBJ & $90.0 \%$ & $82.5 \%$ & $50.0 \%$ & $74.4 \%$ \\
\hline CPLA & $80.0 \%$ & $91.7 \%$ & $67.6 \%$ & $90.9 \%$ \\
\hline CPSM & $85.0 \%$ & $91.7 \%$ & $54.3 \%$ & $50.0 \%$ \\
\hline
\end{tabular}

The analysis also led to consider verbalizations that reflect the way of thinking of the actors that translate a level of unflattering confidence around the trust that teachers have in parents; it is perceived that parents do not adequately fulfill with its role of support for the management that takes place in schools. Teachers say that parents do not always implement co-responsibility as a value that gives support to the actions that are carried out in the school, for example. 
There is less and less responsibility. Now the responsibility remains with the teachers. For me it would be that parents should take more responsibility. Because sometimes, the moment they come to register the registration order, I do not know why they give mistaken data and where also one could not contact them. That way they leave the student as drifting, and one wants to help, but we need their support. We have held meetings and other things, but few parents actually attend. Indeed, they do not all attend, and just those who have problems are those who especially do not attend (EDCFTJGL).

\section{c) Influence of the NSE in the NCA Category.}

Table 12. General results of the NCA by NSE.

\begin{tabular}{lcccc}
\hline \multicolumn{1}{c}{ NCA } & NSE Low-Low & NSE Medium Low & $\begin{array}{c}\text { NSE Medium- } \\
\text { High }\end{array}$ & NSE High \\
\hline Positives & $56.4 \%$ & $70.5 \%$ & $61.3 \%$ & $52.8 \%$ \\
\hline Negatives & $23.8 \%$ & $22.6 \%$ & $32.1 \%$ & $38.5 \%$ \\
\hline Neutral & $19.8 \%$ & $6.8 \%$ & $6.4 \%$ & $8.5 \%$ \\
\hline
\end{tabular}

The comparison of socio-economic factors in the NCA shows a generalized tendency to show less favored positive perceptions and a growing line of negative perceptions. In the low-low NSE, the neutral percentages also grow, probably originated in it because of the low, educative level of the informants of this stratum.

\section{Conclusions.}

As social relations inside and outside the classroom, are supported on experiences and personal experiences, influenced by cultural capitals interacting reciprocally; producing an amalgam between the national, local culture, families and the educational institution. This socio-educational interaction is the core of pedagogical work, and is the key to coexistence and school climate.

Thus, these conclusions are the result of elaborations and reflections that have been forged in the course of the investigation, since the description of the obtained results operated with an annulling effect of several myths that are positioned in the collective imagination of the citizens.

From the analysis of the perceptive records offered by the informants, and with the contribution of theoretical views on the importance of achieving a stable and positive school organizational climate, the following conclusion is reached:

The participating schools of this study, based on the analysis made about the relationship between actors and the level of trust between them, have built a mostly positive school organizational climate which generates spaces favorable to innovation and change processes. 
Positive results are in all categories above $50 \%$, which means that the actors of schools, project a good school climate that is held in the quality of inter-personal behavior between actors in the school, officers: teachers, students, and parents.Therefore accordingly they have been able to establish an atmosphere of harmony and healthy coexistence.

Healthy living results from interactions of respect and commitment around shared objectives and reciprocity in the enjoyment of contact between individuals who support each other and express satisfaction with positive feelings towards a school with which they identify, in line indicated by Mendoza González and Barrera Baca , (2018) .

A school population whose perceptions distance themselves from those of the other actors, sends clear messages that the current conditions of relations within educational establishments should be worked on with clear objectives, in order to avoid a greater decrease in the perceptual levels of the schools, and students, which could produce, in the long run, a negative impact on school performance.

The relations of teachers with their students are spaces, always under construction, in which it is essential to distort the classical logic of distancing between the role of the teacher and the role of the student, without, therefore, lacking ingredients of respect, consideration. and commitment to the task; enforceable characteristic components arranged so that both roles in synergism actually meet the needs of those involved, as indicated in their studies as expressed in Toro Cabrera Alvarez and Gomez (1998) .

Trust is a concept whose meaning appeals, among other things, to have hope in the actions of the other. It is a preferred option to the assumption that the one in whom one trusts will look for favorable results for the other; all this, without endorsement or express guarantee of effective realization.

In the school environment, confidence is built progressively and is associated with the behavior of the actors, as noted ( Huber, Montpoint-Gaillard and Weisheimer, 2018 , Murphy , Tubritt $Y$ Norman , 2018). It also assumes that the organization of the school is aware of these problems. Although the perceptions are mostly positive, there is a minority negative perception in a sector of teaching that perceives that trust in them is cracked day by day in an environment of disparagement of their abilities. This result is interpreted as a decreasing perception, and therefore there should be implemented more and better opportunities for recognition by the management of the actors of the educational communities.

The perception was collected from students in the consolidated data set a less favorable view regarding the level of conflictive activity and attitudes of schools, forms of conflict resolution, the lack of confidence they place and observe among actors of the educational community, and the perception that these factors have a negative influence on the school climate, and the imminence of possible conflicts.

A population of students unmotivated in school and play, yields very few satisfactory answers in the school environment, and raises serious questions about the way these mental representations, positioned in their imaginary influence the success or failure of its management of students. It is clear, as seen in (Garcia Medina , 2018), that the way young people understand and interpret the environment in which they interact, is capable of generating attitudes that promote or undermine integration processes and construction of

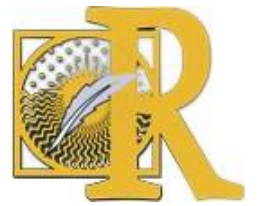


learning; they also affect the configuration of the framework of relationships that interweave in their passage through the educational institution.

In this vein, it is said that schools should construct a reciprocal life in reception areas that adequately respond to the interests and expectations of young people. Well, apparently, the average perceptions do not correspond to a scenario which enhances the dynamic interactions of comprehensive development of students, most likely due to misunderstanding of the adult world with the world of the teenager. The form of conflict resolution is perceived unsatisfactorily.

Educational institutions are called to take into account the interests, expectations, and ways to promote a sensitive approach to knowledge, typical of the new generations, to design and implement strategies that can form a framework of positive interactions as a prelude to a phase of realization of results of learning and satisfaction in the student population, along the lines indicated by (Flickinger, 2018, Romero Pérez and García Fernández, 2018).

Another aspect that affects the perceptions of students is in the eminence of risk that are caused by the problem of micro - trafficking of drugs and narcotics inside and outside the school space. As may be observed, the school is not without the same type of effects that occur in the macro- environment, in a city like Guayaquil, over - populated, characterized by various problems as violence, drug addiction, crime, generating indexes of concern and anguish in teenagers, and influences their perception of the environments in which they develop.

Analysis of the results obtained in the study raises the need to reflect on the effects caused by a neglect of awareness of the central issues in society and the school environment There is the urgent necessity of an educative model in the process of change and innovation, and the need to outline actions that produce commitment and motivation among teachers, but also among students and parents.

\section{References.}

- Asensio Muñoz, I. y Fernández Díaz, M. (1991). El clima de las Instituciones de Educación Superior. Revista Complutense de Educación, 2(3), 501-518. Recuperado de: www.raco.cat/index.php/Educar/article/download/20736/20576

- Delgado Algarra, E.J. (2015). Investigación acción participativa como impulsora de la ciudadanía democrática y el cambio social. IJERI: International journal of Educational Research and Innovation, 3, 1-11.

- Escarbajal Frutos, A., Caballero García, C.M. y Roda Páez, M. (2019). A study of educational situation and family enviroment of students in vulnerable contexts. IJERI: International journal of Educational Research and Innovation, 11, 71-82.

- Fernández Batanero, J.M. (2015). Convivencia escolar. Un estudio en la provincia de Sevilla (España). IJERI: International journal of Educational esearch and Innovation, 3, 78-93.

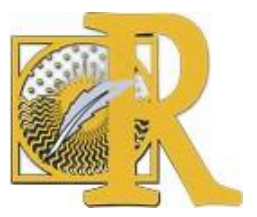


- Flickinger, H.G. (2018). Education and alterity in a multicultural society context. Cadernos de Pesquisa, 48(167), 136-149.

- García Medina, R. (2018). Inclusión y convivencia para prevenir el racismo, la xenofobia y otras formas de intolerancia: uno de los retos principales de nuestro sistema educativo. Ciencia, Técnica y Mainstreaming Social, 2, 53-6.

- Gil López, A.J., Antelm Lanzat, A.M. y Cacheiro González, M.L. (2018). Análisis de la capacidad de innovación escolar desde la perspectiva del profesorado de educación secundaria. La escuela como organización que aprende. Educar, 54(2), 449-468.

- Huber, J., Montpoint-Gaillard, P. y Weisheimer, P. (2018). Pour une école de la convivencia. Cahiers Pedagogiques, 73, 14-16.

- Leiva Olivencia, J.J. (2015). Interculturalidad y estilos de aprendizaje: nuevas perspectivas pedagógicas. IJERI: International journal of Educational Research and Innovation, 3, 36-51.

- McMillan, J. H. y Schumacher, S. (2012). Investigación educativa: una introducción conceptual. Madrid: Pearson.

- Mendoza González, B. y Barrera Baca, A. (2018). Handling of Coexistence in Basic-Level Education: Parent's Perception. Revista electrónica de investigación educativa, 20(2), 93102.

- Ministerio de Educación (2012). Marco Legal Educativo. Quito: Editogran.

- Ministerio de Educación (2013). Informe de Rendición de Cuentas 2012. Quito: Editogran.

- Murphy, E.R., Tubritt, J. y Norman, J.O. (2018). The role of empathy in preparing teachers to tackle bullying. NAER: Journal of New Approaches in Educational Research, 7(1), 17-23.

- Pacheco Salazar, B. (2018). School Violence: The Perspective of Students and Teachers. Revista electrónica de investigación educativa, 20(1), 112-121.

- Retana Alvarado, D.A., De las Heras Pérez, M.A., Vázquez Bernal, B. y Jiménez Pérez, R. (2018). El cambio en las emociones de maestros en formación inicial hacia el clima de aula en una intervención basada en investigación escolar. Revista Eureka sobre enseñanza y divulgación de las ciencias, 15(2), 2602-2619.

- Romero Pérez, E.C. y García Fernández, J. (2018). Contra la violencia, educación popular y ciudadanía global. Revista Padres y Maestros / Journal of Parents and Teachers, 373, 66-71.

- Senplades (2013). Plan Nacional para el Buen Vivir 2013-2017. Quito: Senplades. 
- Toro Álvarez, F. y Cabrera Gómez, H. (1998). Distinciones y relaciones entre clima, motivación, satisfacción y cultura organizacional. Revista Interamericana de Psicología Ocupacional, 17(2), 27-41.

- Weinstein, J. y Raczynski, D. (2018). Construcción y pérdida de la confianza de docentes: un análisis de incidentes críticos. Psicoperspectivas, 17(1), 34-46. 